\title{
Penataan Sistem Demokrasi Indonesia Melalui Pemilu \\ Untuk Kesejahteraan Masyarakat
}

\author{
Naufal Aditya Syam Hayyun, 2191B0002 \\ IIK Strada Indonesia \\ opank.naren@gmail.com
}

\begin{abstract}
Abstrak
Secara konstitusional, Indonesia adalah negara kesatuan yang pemerintahannya berlandaskan pada sistem politik demokrasi. Pemilu secara periodik adalah konsekuensi logis dari pilihan sistem politik demokrasi Indonesia. Melalui eksperimentasi pemilu Indonesia berkomitmen membangun kualitas sistem politik demokrasinya. Sayangnya pemilu yang berjalan di Indonesia sebagian besar masih dipenuhi dengan konflik politik. Setelah sekian lama dikesampingkan dan dilupakan, kini sudah saatnya Indonesia dalam membangun kualitas system politik demokrasinya meletakan kebebasan sipil, hak politik, dan lembaga pemilu dengan bingkai integrasi bangsa. Beberapa aspek dari standard tersebut, dengan beberapa penekanan pada aspek hak pilih warga negara dan kelembagaan demokratis yang menjadi syarat adanya pemilu demokratis tersebut. Pembahasan selanjutnya akan diarahkan pada aspek sosial dan politik dari pemilu-pemilu di Indonesia. Meskipun pemilu bukan hanya satu-satunya instrumen demokrasi, tetapi peran pemilu tidak bisa dipungkiri sangat vital. Bahkan, keberadaan pemilu mengindikasikan sebuah negara mengadopsi sistem politik demokratis. Indikasi pemilu yang bebas dan adil mencakup keberadaan sentimen yang merefleksikan popularitas secara sadar. Sesuatu yang timbul sebagaimana masyarakat merasakan proses berkonsultasi sosial. Pemilu dikatakan demokratis beserta syarat-syaratnya secara Internasional serta evaluasi pelaksanaan pemilu konteks sosial dan politik yang ada, konfigurasi politik yang berjalan serta kaitannya dengan aspek yuridis dari pemilu yang jujur dan adil.
\end{abstract}

Kata Kunci: Demokrasi, pemilu

\section{PENDAHULUAN}

Bangsa Indonesia merupakan satu kesatuan yang menjunjung keterbukaan di mana semua warga negara yang sudah mempunyai hak memilih dalam menentukan untuk memilih wakilnya di parlemen maupun pemimpin dalam penyelenggaraan negara (Sardini, 2011). Tentu saja dalam memilih wakil dan pemimpin tersebut dilakukan berdasarkan berbagai pertimbangan sesuai dengan hati nurani serta keterwakilan dari masyarakat itu sendiri. Di Negara Kesatuan Republik Indonesia kegiatan tersebut dilaksanakan melalui wadah yang dikenal dengan pemilihan umum yang diperuntukkan bagi kesejahteraan masyarakat. Selanjutnya, mereka berharap dengan terpilihnya wakilwakil rakyat dan pemimpin ini dapat membawa kepada tingkat kesejahteraan yang diinginkan.

Hal ini disadari bahwa masyarakat tidak memiliki wewenang dan kekuasaaan dalam menjalankan pemerintahan. Hanya 
melalui pemilihan umum ini dianggap sebagai cara memberikan kekuasaan dan kewenangan kepada wakil dan pemimpin tersebut untuk menjalankan pemerintahan dalam rangka mewujudkan kepastian hukum secara adil dan jujur (Anshori, 2014). Dalam menjalankan kekuasaaannya, pemerintah harus menyandarkan pada dasar hukum yang pasti yaitu, dengan melaksanakan Undang-Undang Dasar 1945 secara utuh mulai dari pembukaan, batang tubuh dan lampiran. Dengan demikian, pemilihan umum tiada lain adalah dimaksudkan dalam rangka melaksanakan amanat Undang-Undang Dasar ini sehingga kedaulatan benarbenar berada di tangan rakyat karena memegang kendali atas jalannya pemerintahan. Oleh karena itulah bahwa rakyat mesti memilih wakilwakilnya sesuai kriteria untuk duduk di parlemen ataupun pemerintahan.

Pada negara-negara yang menganut sistem demokrasi, termasuk Indonesia, penyelenggaraan pemilihan umum di samping untuk menyeleksi penyelenggara negara juga dimaksudkan sebagai proses edukasi kepada masyarakat untuk mewujudkan kedaulatan rakyat dan memastikan kekuasaan berada di tangan rakyat. Melalui pemilihan umum setidaknya akan terjadi pergantian atau peralihan kekuasaan berdasarkan hasil pemilihan yang sesuai dengan prinsipprinsip yang ditetapkankan oleh konstitusi (Asshidiqie, 2013).

Pemilihan umum merupakan proses memilih atau menentukan seseorang untuk mengisi jabatan politik tertentu dan merupakan pesta demokrasi yang sudah lama dilaksanakan di Indonesia. Pemilu yang melibatkan Warga Negara Indonesia yang sudah berhak memilih wakil-wakil rakyat beserta pemimpin yang akan duduk di kursi pemerintahan. Dengan pemilihan tersebut diharapkan bangsa Indonesia memiliki para pemimpin dan wakil rakyat yang sesuai dengan harapan masyarakat Indonesia. Tentu saja pemimpin yang diharapkan itu adalah pemimpin yang mampu membawa kebaikan dan mengantarkan Indonesia menjadi negara yang maju, makmur, dan sejahtera. Ini merupakan harapan setiap orang.

\section{METODE PENELITIAN}

Studi ini menggunakan metode penelitian studi pustaka dan analisis deskriptif sehingga akan memberikan kontribusi yang bersifat konseptual terhadap penyebab pergeseran dan bentuk konstelasi parpol di Indonesia. Secara umum tawaran konseptualisasi ini dapat menjadi salah satu alat untuk memahami orientasi dan perilaku partai di negara demokrasi baru.

\section{PENUTUP}

Hampir semua partai politik di Indonesia saat ini, merupakan partai baru atau setidaknya merupakan "peranakan" dari partai lama yang mengalami perubahan pelembagaan dan karakteristik seiring dengan dinamika yang berkembang pasca reformasi. Sedangkan partai-partai yang sebelumnya telah terbentuk sejak Orde Baru (Golkar dan PPP), dituntut untuk beradaptasi dengan perubahan baik di internal dan eksternal partai. Bagi partaipartai baru yang kemudian gagal memperoleh kursi, atau memperoleh sedikit kursi kemudian tersingkir sejak tahun 2009 karena aturan parliamentary threshold, atau bertahan hingga pasca pemilu 2014, partaipartai ini cenderung memanfaatkan potensi pragmatis yang berkembang. Partai-partai inilah yang dalam artikel ini dikategorisasikan sebagai match-all party.

Ciri khas yang tampak oleh partaipartai match-all, dan tak tertangkap dalam klasifikasi spesies partai elektoralis 
Gunther dan Diamond, adalah pada ketiadaan atau minimnya modal sosial sebelum partai ini lahir dan berkembang. Figur menjadi instrumen utama dalam pasar politik, di samping jargon platform dan program yang kerap tak menarik perhatian pemilih. Lemahnya figur dan konsistensi program, menjadikan partai kategori match-all harus memanfaatkan segala kemungkinan dan kondisi yang memberikan mereka keuntungan baik dalam dimensi citra maupun materiil. Gerak politik match-all party mengabaikan pembatasan ideologi, platform dan strategi untuk mengimplementasikan programprogramnya.

Pada pemilu dan pasca pemilu 2014 kecenderungan bertindak sebagai partai match-all kian tampak. Pertama, semua kandidat yang diusung partai, mencoba menjajaki kerjasama politik dengan semua kandidat lain, tanpa melihat kesesuaian ideologi, platform dan program. Sepanjang proses tersebut, kemungkinan kegagalan mengawinkan bakal kandidat terjadi ketika tidak ada titik temu soal berapa dan apa bagian kue kekuasaan yang diperoleh. Hal tersebut tampak pada tingginya intensitas safari politik yang dilakukan oleh bakal kandidat dengan melakukan penjajakan hampir pada semua partai. Kedua, diakomodirnya sejumlah perwakilan partai ke dalam kabinet. Walaupun tak lagi ketua umum, tetapi hal ini juga merefleksikan pola kecenderungan ke arah model partai match-all. Dalam komposisi kabinet, terlihat tidak ada partai yang tidak diakomodir kepetingannya. Ketiga, tidak ada jaminan peta koalisi tidak berubah sepanjang pemerintahan terpilih berjalan. Selama terdapat kemungkinankemungkinan yang memberi keuntungan, dikotomi pendukung pemerintah dan oposisi akan bersifat cair karena selalu terdapat kompromi dan akomodasi dari semua partai.

\section{DAFTAR PUSTAKA}

Widianingsih, Y. (2017). Demokrasi dan pemilu di indonesia: suatu tinjauan dari aspek sejarah dan sosiologi politik. Jurnal signal, 5(2).

Santika, I. G. N., Purnawijaya, I. P. E., \& Sujana, I. G. (2019). Membangun Kualitas Sistem Politik Demokrasi Indonesia Melalui Pemilu Dalam Perspektif Integrasi Bangsa Dengan Berorientasikan Roh Ideologi Pancasila. In Seminar Nasional Hukum Dan Kewarganegaraan (Vol. 1, No. 1, pp. 74-85).

Hayyun, N. A. S. (2021, November 1). TOLERANSI ANTAR UMAT BERAGAMA DAN MEMPERKOKOH PERSATUAN DAN KESATUAN BANGSA.

Hayyun, N. A. S. (2021, October 12). Artikel Pengaruh Narkoba Bagi Remaja.

Hidayat, A. (2020). Manfaat Pelaksanaan Pemilu untuk Kesejahteraan Masyarakat. Politicon: Jurnal Ilmu Politik, 2(1), 61-74.

Aminuddin, M. F., \& Ramadlan, M. F. S. (2015). Match-All party: pragmatisme politik dan munculnya spesies baru partai politik di Indonesia pasca Pemilu 2009. Jurnal Politik, 1(1), 39-74.

Warjiyati, S. (2020). Penataan Struktur dan Kewenangan Komisi Pemilihan Umum, Badan 
Pengawas Pemilu dan Dewan Kehormatan Penyelenggara Pemilu dalam Upaya Mewujudkan Pemilihan Umum yang Demokratis di Indonesia. ARISTO, 8(1), 27-41. 